\title{
EVALUATION OF AN ANTIGEN-ANTIBODY "COMBINATION" ENZYME LINKED IMMUNOSORBENT ASSAY FOR DIAGNOSIS OF HEPATITIS C VIRUS INFECTIONS
}

\author{
Odari E.O ${ }^{1,2}$, Budambula N.L.M ${ }^{2}$, Nitschko $\mathbf{H}^{1}$
}

\begin{abstract}
BACKGROUND: Development of “combination" assays detecting in parallel, within a single test, Hepatitis C Virus (HCV) antigens and antibodies, not only reduces the window period in $\mathrm{HCV}$-infection but also costs. Reduction of costs is important for developing countries where money and personal resources are limited.

METHODS: We compared the Monolisa ${ }^{\circledR}$ HCV Antigen-Antibody Ultra (Bio-Rad Laboratories Limited, Marnes La Coquette, France) with the AXSYM HCV version 3.0 (Abbot Diagnostics, Germany)-the latter assay detecting only antibodies to HCV. Seventy three HCV-PCR positive and negative samples were tested.

RESULTS: Although the two assays showed comparable results, two samples from a bone marrow transplant (BMT) patient of viral loads $7.8 \times 10^{5}$ and $8.9 \times 10^{6} \mathrm{IU} / \mathrm{mL}$ could not be detected by the Monolisa ${ }^{\circledR}$ HCV Antigen-Antibody Ultra assay. Failure to detect the two samples with viral loads considered above threshold of detection for antigen proteins suggested a lack of sensitivity by this assay to discover viral capsid protein in patient samples. Genotyping of these samples revealed genotype $1 b, a$ $H C V$-subtype which is widespread and should thus be easily detected.

CONCLUSION: We conclude that although this assay depicts high sensitivity and specificity in detecting antibodies to $\mathrm{HCV}$, it seems not to add further benefit in our study population to detect $\mathrm{HCV}$ infections by enhanced sensitivity due the potential contingency to trace viral capsid antigens.
\end{abstract}

KEY WORDS: Ag-Ab Combination assay, Hepatitis C Virus, ELISA, Monolisa HCV Ag-Ab Ultra

DOI: http://dx.doi.org/10.4314/ejhs.v24i4.10

\section{INTRODUCTION}

Hepatitis $\mathrm{C}$ virus (HCV) remains a major health care burden globally. It is currently estimated that 170 million people suffer from $\mathrm{HCV}$ chronic infections worldwide (1). The highest prevalence rates are still reported in Africa, Eastern Mediterranean, South East Asia and the Western Pacific. True incidence rates across the world continue to fluctuate. In developing countries exact incidence rates have been difficult to calculate given the asymptomatic, often latent nature of the disease prior to clinical presentation. Further prevalence rates across the developed world are changing since more countries are now aware of transfusion-related HCV. Many regions still use blood donors to report the prevalence of $\mathrm{HCV}$ infection. Using blood donors may underestimate the true prevalence since they represent generally a highly selected population.

Studies show intravenous drug use as the leading risk factor for the spread $\operatorname{HCV}(2,3)$ while others include transfusion of blood and blood products as well as hemodialysis (4-7) and sexual route of transmission (8-10). Therefore, the complexity and uncertainty related to the geographic distribution, chronic HCV, determination of its associated risk factors and

\footnotetext{
${ }^{1}$ Max von Pettenkofer Institute for Hygiene and Medical Microbiology - LMU, Munich, Germany

${ }^{2}$ Jomo Kenyatta University of Agriculture and Technology, Nairobi, Kenya

Corresponding Author: Odari E.O, Email: Kodarie04@yahoo.com
} 
evaluation of cofactors accelerating its progression, underscore the difficulties in global prevention and control of $\mathrm{HCV}$.

Contrary to industrialized countries where anti-HCV screening and mini-pool nucleic acid amplification testing (NAT) is done on all collected blood hence a reduction in transmission, transfusion related transmission remains critical for many developing countries. The fact that $\mathrm{HCV}$ shows no clear clinical signs during the long window period further complicates the risk of transmission through other routes to the general population. Infection with $\mathrm{HCV}$ in Human Immunodeficiency Virus (HIV) infected could lead to an increased rate of progression to acquired immune-deficiency syndrome (AIDS), hamper immune reconstitution of patients and aggravate the risk of hepa-toxicity especially in patients on HIV treatment. Indeed, HCV infection has been reported to increase the number of complications in persons co-infected with HIV (11). With the increasing number of cases of $\mathrm{HIV} / \mathrm{HCV}$ coinfection in Africa (12-16), there is a need for early $\mathrm{HCV}$ diagnosis so as to enhance optimum treatment and management of HIV patients. This would reduce possible complications resulting from dual infections.

Apart from early detection of HCV infection, combined antigen/antibody ELISA assays would be used for detection in the immune-suppressed or immune-deficient patients including HIV positive or patients with a history of bone marrow transplantation (BMT). Such patients show increased risk of serious veno-occlusive disease (VOD) of the liver (17-21). With recovery of cellular immunity after transplantation, severe hepatitis and fulminant liver failure may occur (22). In the absence of humoral or immediate cell mediated response in these patients, a rapid viral replication would lead to the production of various antigens. Today with BMT history of over 30 years, infection in long term survivors requires regular HCV follow-up assays and viral load tests.

This study aimed at evaluating the diagnostic performance of Monolisa ${ }^{\circledR} H C V$ Ag-Ab ULTRA (Bio-Rad) ELISA kit for simultaneous detection of HCV Antibodies and capsid antigens patients samples.

\section{MATERIALS AND METHODS}

Study design: The study involved both retrospective and prospective laboratory-based analysis of 73 (47 positive and 26 negative) archived plasma samples between May and September, 2012. The positive samples included a panel of 7 samples obtained at different time points from a BMT patient. Samples had been stored at $-20^{\circ} \mathrm{C}$ before analysis and were used with permission from the virology department of the Max von Pettenkofer-Institute in Munich, Germany, where testing of the same samples was done.

Test principle for Monolisa ${ }^{\circledR} \mathrm{HCV} A g-A b$ ULTRA detection kit: Monolisa ${ }^{\circledR} H C V A g-A b$ ULTRA assay is an enzyme immunoassay designed to detect both the capsid antigen and antibodies in serum or plasma. A micro-plate is coated with monoclonal antibodies against the capsid protein of $\mathrm{HCV}$ and two recombinant proteins produced in E. coli; one from the NS3 region (genotype 1 and $3 \mathrm{a}$ ), and a recombinant antigen from the non-structural region NS4. A mutated peptide from the capsid structural region is also immobilized on the plate. Two conjugates are involved; conjugate 1 (R6) is a mouse biotinylated monoclonal antibody against the $\mathrm{HCV}$ capsid (it does not react with the HCV capsid mutated peptide coated on the micro-plate), Conjugate 2 (R7) is a mouse peroxidase-labeled antibody to human IgG and peroxidase-labeled streptavidin.

Test evaluations and sample characterization: The samples were first tested by "antibody only" ELISA kits (AxSYM HCV version 3.0 (Abbott Diagnostics, Germany) and Ortho® HCV 3.0 with Enhanced SAVe (Ortho-Clinical Diagnostics, United Kingdom)) before amplification by PCR. Samples giving conflicting results by the ELISA kits were tested by western blot (INNO-LIA HCV score, Innogenetics ${ }^{\circledR}$ N.V, Belgium). Plasma HCV RNA quantification was performed by real time PCR using an in-house assay with internal positive controls. Based on the results, samples were categorized as; (1) HCV-RNA positive, (2) antibody positive-HCV-RNA negative, (3) HCV antibody negative-HCV-RNA negative, and (4) HCV-RNA positive BMT serial samples obtained over a period of 276 days.

Sensitivity: The 47 positive samples ( $31 \mathrm{HCV}$ RNA positive, 9 antibody positive- HCV-RNA 
negative and $7 \mathrm{HCV}$-RNA positive serial samples) were used to evaluate the sensitivity of the assay. The 31 HCV-RNA positive samples were of genotypes 1 to 4 and a "mixed" genotype, with viral loads from $4 \times 10^{4} \mathrm{IU} / \mathrm{mL}$ to $29 \times 10^{6} \mathrm{IU} / \mathrm{mL}$, whereas the 7 serial samples were of genotype $1 \mathrm{~b}$ measuring from $3 \times 10^{3}$ to $10 \times 10^{6} \mathrm{IU} / \mathrm{mL}$. Genotyping of plasma samples was determined by Restriction Fragment Length Polymorphism (RFLP), and where RFLP failed, the samples were sequenced and blasted in the HCV database for determination. Genotypes determined included 1a (4/31), 1b (7/31), 2a (5/31), 2b (1/31), 3a (6/31), 4 $(7 / 31)$ and "mixed" [1a, 3b and 4] (1/31).

Specificity: Specificity was evaluated using 26 negative samples selected from a group of patients with no known risk of $\mathrm{HCV}$ infection who attended the hospital for regular checkups.

Test procedures: Test procedure for Monolisa ${ }^{\circledR}$ $H C V A g-A b U L T R A$ was performed following the instructions of the manufacturer. Briefly, the diluted washing solution and the working antigen positive control were freshly prepared. The following components were added into the plate; $100 \mu \mathrm{L}$ of conjugate $1(\mathrm{R} 6)$ was added into each well, $50 \mu \mathrm{L}$ of negative control serum (R3) in well $\mathrm{A} 1,50 \mu \mathrm{L}$ of antibody positive control serum (R4) into $\mathrm{B} 1, \mathrm{C} 1$ and $\mathrm{D} 1,50 \mu \mathrm{L}$ of working antigen positive control into well $\mathrm{E} 1$ and $50 \mu \mathrm{L}$ of patient samples into in well F1 and the succeeding wells. The materials were mixed for 5 seconds covered with an adhesive film and incubated for 1 hour at $37^{\circ} \mathrm{C}$. After incubation the plates were washed five times using $400 \mu \mathrm{L}$ of washing solution before addition of $100 \mu \mathrm{L}$ of conjugate- 2 solution (R7) and a further incubation at $37^{\circ} \mathrm{C}$ for 30 minutes. After another 5-step wash, $80 \mu \mathrm{L}$ of freshly prepared enzymatic development solution was added followed by a 30 minutes' incubation in the dark at room temperature. The reaction was finally stopped using $100 \mu \mathrm{L}$ stopping solution (R10) and the optical density (OD) measured at $450 / 620 \mathrm{~nm}$ using a "Sunrise" ELISA reader.

The presence or absence of antibodies to $\mathrm{HCV}$ or/and HCV capsid antigen was determined by comparing the recorded absorbance for each sample with the calculated cut-off value. The cutoff value was determined by dividing the mean of the OD readings for the three positive controls by 4. Readings below the cut-off were considered non-reactive; samples below the cut-off value by less than $10 \%$ were retested. Samples above the cut-off values were considered initially reactive and retested in duplicate before a final interpretation was made. Results were compared with those of AxSYM HCV version 3.0 for the same samples.

Data analysis: Data were analyzed using GraphPad prism 5 statistical software. Pearson's correlation $\left(\mathrm{R}^{2}\right)$ was used to correlate viral load against OD for ELISA assays. Sensitivity and specificity of the assays were tested using PCR and Western Blot Assays as the gold standards.

\section{RESULTS}

Overall performance of Monolisa ${ }^{\circledR} \mathrm{HCV}$ Ag-Ab ULTRA assay kit (sensitivity, specificity and predictive values).

As shown in table 1 , the two assays equally detected all the 31 HCV-RNA positive samples, and for each assay 4 out of 7 serial samples. Results, however, varied within HCV-RNA negative-antibody positive and the HCV-RNA negative-antibody negative samples.

Table 1: Suspected Hepatitis C samples tested with AXSYM and Monolisa Ag/Ab ELISA kits (n=73)

\begin{tabular}{lllclc}
\hline Test samples & & AXSYM & & \multicolumn{2}{c}{ Monolisa ${ }^{\circledR} \boldsymbol{H C V} \boldsymbol{A g}$ - $\boldsymbol{A b}$} \\
Sample type & Total & Reactive & Non-Reactive & Reactive & Non- Reactive \\
\hline PCR positive samples & 31 & $3(100 \%)$ & 0 & $31(100 \%)$ & 0 \\
Antibody positive- PCR negative & 9 & $9(100 \%)$ & 0 & $8(88.9 \%)$ & $1(11.1 \%)$ \\
HCV negative samples & 26 & $1(3.8 \%)$ & $25(96.2)$ & 0 & $26(100 \%)$ \\
Bonemarrow transplant patient & 7 & $4(57.1 \%)$ & $3(42.9 \%)$ & $4(57.1 \%)$ & $3(42.9 \%)$ \\
\hline Total & $\mathbf{7 3}$ & $\mathbf{4 5}$ & $\mathbf{2 8}$ & $\mathbf{4 3}$ & $\mathbf{3 0}$ \\
\hline \hline
\end{tabular}

Sensitivity and Specificity: In the first case, the overall sensitivity and specificity was calculated for the two assays using the 73 samples. As shown in table 2 a higher sensitivity was realized with 
AxSYM HCV version 3.0, and a likelihood ratio of 24.34, compared to Monolisa® $\mathrm{HCV} A g-A b$ ULTRA assay kit. Since false negative results only occurred in the BMT panel, a second analysis was done excluding this panel mainly to observe the performance of the assay on individual samples devoid of the effect of the serial samples. There was a general improvement in sensitivity in both assays, once more a likelihood ratio of 26.0 was realized for AxSYM HCV version 3.0. Table 2 shows sensitivity and specificity results for the two ELISA assays. An improved sensitivity results was obtained for both assays when the samples from the BMT patient were excluded from the analysis. Likelihood ratios of 24.3 and 26.0 were obtained in the general and partial analyses respectively.

Table 2: Sensitivity, specificity and predictive values of Monolisa Ag/Ab and AxSYM HCV version 3.0 ELISA assays

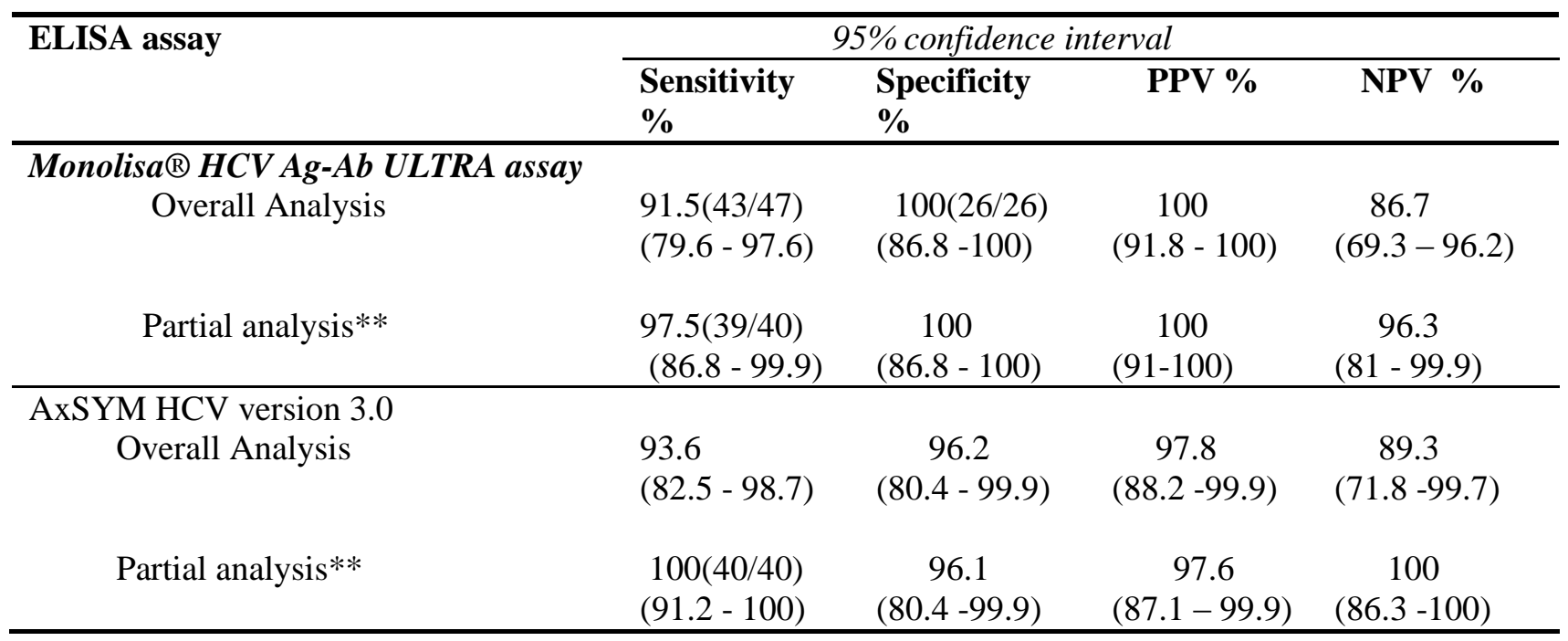

** 7 samples in the BMT sample panel excluded from the analysis

Viral load versus optical density: Evaluation of Monolisa ${ }^{\circledR} \quad H C V \quad A g-A b \quad U L T R A$ assay and AxSYM ELISA kits was further done with samples of different viral loads. The samples included those below the theoretical threshold of $260,000 \mathrm{IU} / \mathrm{mL}$ (approximately $13.7 \mathrm{pg}$ of total $\mathrm{HCV}$ core antigen)(23, 24) calculated for Monolisa® HCV Ag-Ab ULTRA assay kit (25). No significant correlation was observed between viral loads and the optical density; $\mathrm{r}(32)=.097 ; \mathrm{p}=.60$ for Monolisa ${ }^{\circledR} H C V$ Ag-Ab ULTRA assay (Fig. 1) and $\mathrm{r}(32)=.082 ; \mathrm{p}=.66$ for AxSYM HCV version 3.0 (Fig. 2). The finding confirmed the earlier observation during the study where some samples of $8.9 \times 10^{6} \mathrm{IU} / \mathrm{mL}$ and $7.8 \times 10^{5} \mathrm{IU} / \mathrm{mL}$ were not detected by the two assays. 
Fig 1: Optical density versus viral load for

Monolisa Ag-Ab Ultra ( $\mathrm{n}=32$ )

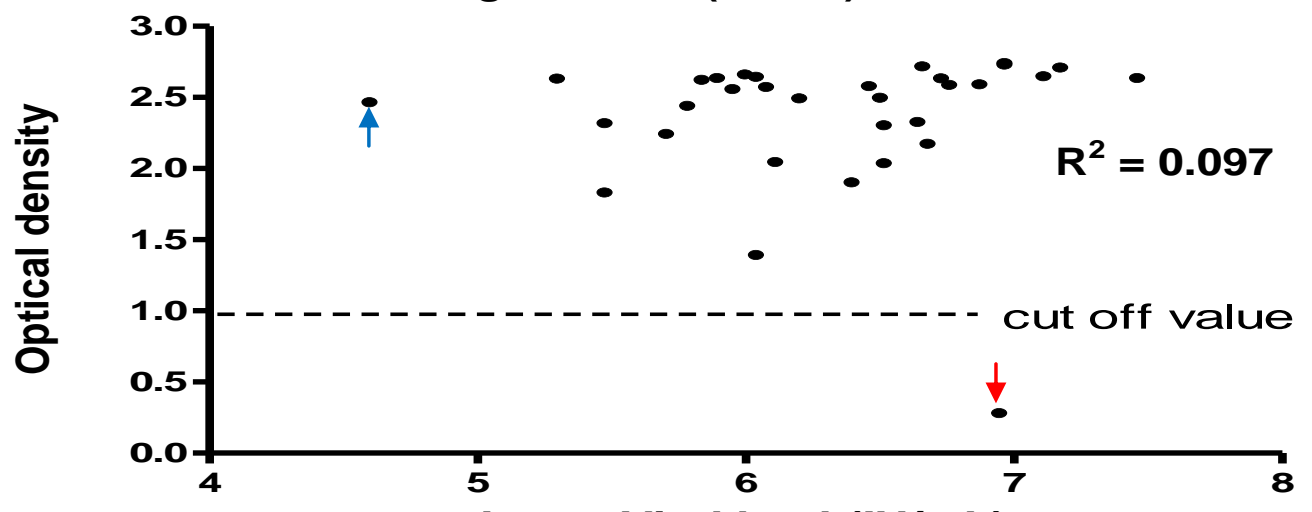

Figure 1 shows no correlation $\left(R^{2}(32) \underline{\mathbf{L}} \mathbf{1} \mathbf{1 0}\right.$.097) Vetween viral load and optical density signals for Monolisa Ag-Ab Ultra assay. One sample of approximately $10 \times 10^{6} \mathrm{IU} / \mathrm{mL}$ was not detected (red arrow) since OD fell below the cut off value, whereas one sample below $1 \times 10^{5} \mathrm{IU} / \mathrm{mL}$ (blue arrow) was detected.

Fig 2: Optical density versus viral load for $A x S Y M A b$

ELISA $(n=32)$

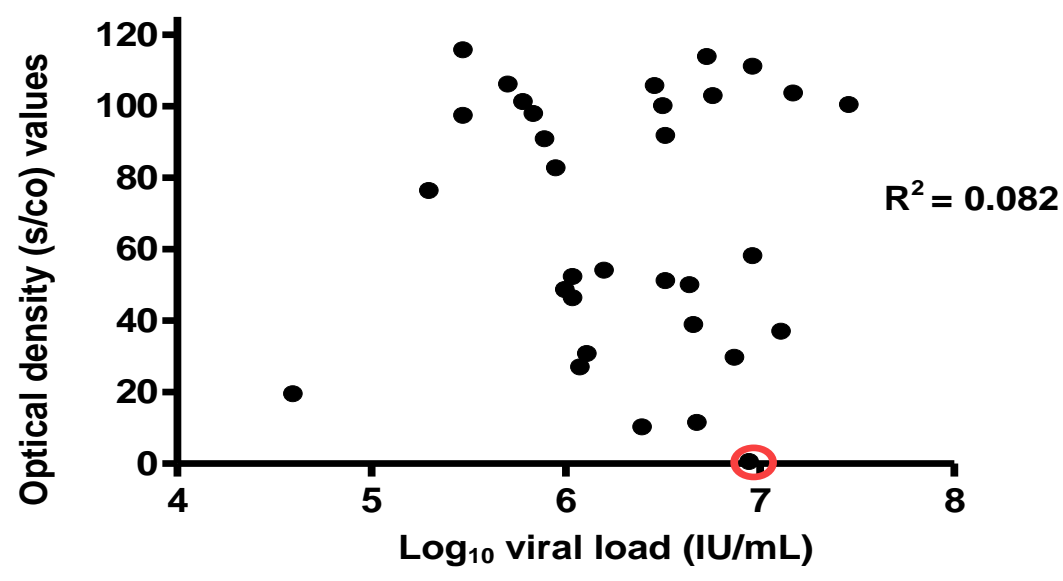

Figure 2 shows no correlation $\left(R^{2}(32)=0.082\right)$ between viral load and optical density signals for AxSYM, antibody ELISA. One sample of approximately $10 \times 10^{6} \mathrm{IU} / \mathrm{mL}$ (circled in a red ring) was not detected since the OD was below the cut off value $(\mathrm{s} / \mathrm{co}=1.0)$, whereas on sample below $1 \times 10^{5} \mathrm{IU} / \mathrm{mL}$ was detected.

Samples from a Bone Marrow Transplant (BMT) patient: Since immune reconstitution after bone marrow transplantation has been studied (26-33) and found to vary between 6 months to over 2 years, detection of antibodies during this period remains minimal. The BMT samples were used to evaluate the efficacy in antigen detection by Monolisa ${ }^{\circledR}$ HCV Ag-Ab ULTRA assay. This capacity would be important if this assay would be used in immunocompromised patients. The BMT samples were of genotype $1 \mathrm{~b}$, a genotype that is less responsive to alpha-interferon therapy compared to genotypes 2 and 3 (34), and is mainly found in the Americas, Europe and parts of Asia. All the detections were only observed in the preBMT samples (Fig. 3) with no detection on samples collected up to 276 days (about 9 months) post transplant. The ODs post transplant was below the cut-off-limits $(0.5$ and 1$)$ of the 2 


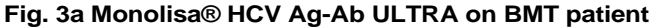

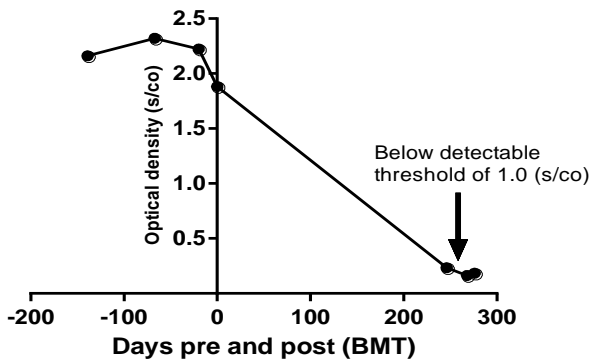

Fig. 3b AxSYM version 3.0 on BMT patient

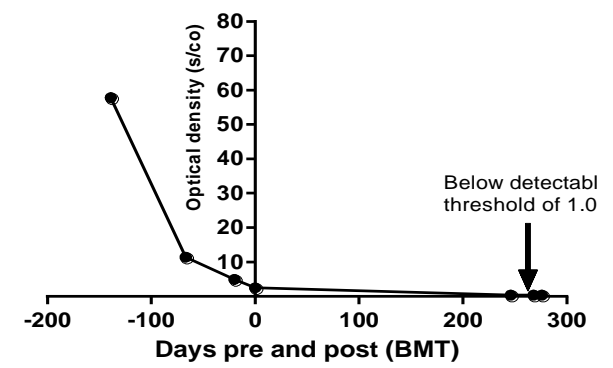

Fig. 3 Detection of HCV in plasma of a BMT patient

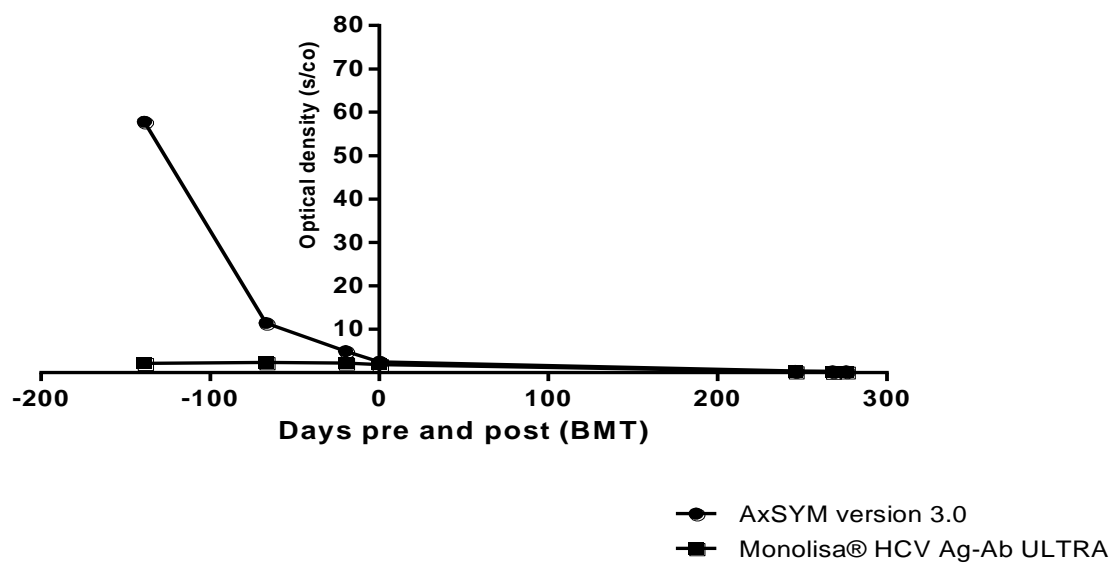

Figure 3 shows results of ELISA tests from plasma of a BMT patient obtained pre and post bone marrow transplant. All samples obtained before bone marrow transplant were positively detected (Figure $3 a$ and $3 b$ ), whereas all samples collected more than 200 days after transplantation were not detected by the 2 assays.

\section{DISCUSSION}

ELISA assays combining antibody and antigen detections in a single kit have been developed and introduced in the field of HIV diagnosis (35). Introduction of similar assays for detecting acute $\mathrm{HCV}$ infection, which previously relied on classical serological methods (36), offers advantages over the existing antibody "only" assays mainly on early detection and detection in immunocompromised population.

Despite the anticipated advantages of "combination" assays, we report the failure of Monolisa ${ }^{\circledR}$ HCV Ag-Ab ULTRA to detect three PCR positive samples of genotype $1 \mathrm{~b}$ from a BMT patient, despite the high viral loads in 2 samples. A similar study (25) also reported failure of Monolisa ${ }^{\circledR} H C V A g-A b$ ULTRA assay to detect a genotype $1 \mathrm{~b}\left(8.19 \times 10^{6} \mathrm{IU} / \mathrm{mL}\right)$ and a genotype $3 \mathrm{a}$ $\left(7.76 \times 10^{6} \mathrm{IU} / \mathrm{mL}\right)$ samples. Further a genotype 4 $\mathrm{HCV}$ positive sample could not be detected by this assay despite the fact that the virus had a normal core sequence (37). These findings of failure to detect samples with high viral loads have a significant implication for this assay designed to detect both antigen and antibody proteins.

Arguably, HCV as a member of Flaviviridae family has an icosahedral capsid of $\mathrm{T} 3$ or $\mathrm{T} 4$ symmetry with 180 or 240 core protein subunits. Since one RNA genome contains 240 subunits of core protein of a molecular mass $19 \times 10^{3} \mathrm{Da}$, one picogram (pg) of virus core corresponds to $1.3 \mathrm{x}$ $10^{5} \mathrm{HCV}$ genome molecules. Some studies even indicate lower ratios of viral particles per pg of proteins, for example in one study the ratio never $\begin{array}{lllllllll}\text { exceeded } & 2 & \mathrm{x} & 10^{4} & \mathrm{IU} / \mathrm{mL} & (6 & \mathrm{x} & 10^{4}\end{array}$ 
genomes/pg)(38), whereas another study estimated an average $8 \times 10^{3} \mathrm{IU} / \mathrm{mL}$ per pg of core proteins $\left(5 \times 10^{3} \mathrm{IU} / \mathrm{mL}\right.$ to $1.2 \times 10^{4} \mathrm{IU} / \mathrm{mL}$ per $\mathrm{pg}$ of proteins) (39). The latter findings were supported by our in-house results (unpublished data) which showed an antigen detection limit of $1.5 \mathrm{pg} / \mathrm{mL}$ for the core antigen corresponding to $1.6 \times 10^{4}$ $\mathrm{IU} / \mathrm{mL}$. Based on these calculations, we note that less than $15 \%$ of core proteins are associated with $\mathrm{HCV}$ particles containing RNA and 240 core subunits, whereas the remaining $85 \%$ of the protein are associated with structures lacking $\mathrm{HCV}$ RNA. These structures have previously been described (40). The latter argument would explain the results realized in figure 1 where 2 samples with viral loads below the theoretical threshold were easily detected by this assay. These samples also showed higher optical signals compared to some samples with higher viral loads.

We however note that a similar trend of results shown in figure 1 was also realized in figure 2 where the 2 samples were again detected by the "antibody only" kit. The similarity in the trend of detection by the 2 different assays pointed towards the fact that the optical signals for these 2 samples were generated by the antibodies as opposed to antigens in the samples. This argument is strengthened by the fact that, upon generation of antibodies by the immune system, viral loads normally decline. The above argument therefore supports the view that Monolisa ${ }^{\circledR} H C V A g-A b$ ULTRA assay, as composed, is inclined to antibody detection than core antigens.

The two samples with viral loads above the threshold limit which were not detected by Monolisa ${ }^{\circledR}$ HCV Ag-Ab ULTRA assay similarly elicit various arguments about the assay. Some studies have failed to demonstrate the presence of antigens in RNA positive sera, for example, in one study,(41) antigens were not detected in sera despite measuring between $10^{5} \mathrm{IU} / \mathrm{mL}$ and $8.2 \mathrm{x}$ $10^{5} \mathrm{IU} / \mathrm{mL}$. In the latter study, some samples below $8.5 \times 10^{5} \mathrm{IU} / \mathrm{mL}$ were detected. Other studies have also demonstrated that analytical sensitivity of antigen assays does not constantly correspond the HCV- RNA titer (42). In the latter study 14 sera $10^{5}$ and $10^{6} \mathrm{IU} / \mathrm{mL}$ remained negative, while 12 sera below $10^{5} \mathrm{IU} / \mathrm{mL}$ tested positive to antigen. Similar results as obtained by Monolisa ${ }^{\circledR} H C V$ Ag-Ab ULTRA assay were also realized by AxSYM assay, a clear indication that the samples contained antibodies below the detectable limits possibly due to immunosuppression as a result of BMT. The fact that Monolisa ${ }^{\circledR} \quad H C V \quad A g-A b \quad U L T R A$ assay detected all the BMT samples before transplantation, rules out the presence of antigens but only points towards antibody detection

Our observations therefore suggest that the diagnostic performance of this "combination" assay is inclined towards antibody than antigen detection, if any. Similar findings with "combo" assays in HIV diagnosis have been reported (43). A closer look at the results obtained by Laura Dean's group (44) in their evaluation of Monolisa ${ }^{\circledR} H C V A g-A b$ ULTRA assay kit using different panels tend to suggest the same for this assay.

The overall sensitivity of $91.5 \%$ (with a higher sensitivity of $97.5 \%$ when BMT samples were excluded) and a specificity of $100 \%$ for Monolisa ${ }^{\circledR} \quad H C V \quad A g-A b \quad U L T R A$ assay kit correspond to those reported in similar studies (42, 45-49). The ability of this assay to distinguish as negative a sample which had been falsely detected as antibody positive-HCV-RNA negative by AxSYM HCV version 3.0 ELISA but categorized as "indeterminate" by Ortho ${ }^{\circledR} \mathrm{HCV} 3.0$ with Enhanced SAVe (and only resolved by western blot as negative), points towards its perfect discriminatory ability, hence specificity of the assay. Indeed, the mean absorbance value within the negative samples of $0.083(0.033-0.219)$ was less than $30 \%$ of its cut off value of 0.327 . This performance is comparable to those of ELISA kits routinely used in screening for blood-transmitted infections such as hepatitis B virus (HBV) and HIV infections. Such discriminatory ability has also been reported by Ansaldi (41), with a specificity of $100 \%$ for this same assay platform and by Dean's group (44). It is, however, important to note that the results obtained in this study were not from sero-conversion panels, where many of Monolisa ${ }^{\circledR}$ HCV Ag-Ab ULTRA assay kit studies has been based, and as such these results cannot be used conclusively to predict the performance of this assay kit among seroconversion samples. Further limitation of the study included low number of samples, hence the need for an increased number of samples. Although samples were also selected to reflect global distribution of genotypes, there is a need to 
use a large number of samples mainly from immunocompromised patients of African origin, since eventually; this assay would be more beneficial to limited resource settings such as in Sub-Saharan Africa.

In conclusion, this study emphasizes, that although Monolisa ${ }^{\circledR} H C V A g-A b U L T R A$ assay kit presents an impressing sensitivity and specificity, the protein detection is more of antibody- than antigen-based. Even though we could not intensively test for antigen sensitivity, our results did not suggest any antigen sensitivity. In their analysis of window period samples, Laperche's group suggested the implementation of this assay in countries where only HCV antibody screening is the efficient measure of improving blood safety (50). A closer look at their results shows a low sensitivity of Monolisa ${ }^{\circledR} H C V$ Ag-Ab ULTRA assay in RNA positive-antibody negative samples where only $1 / 3$ of such samples were detected among blood donors and less than $1 / 2$ detected in hemodialysis panel (50). We, therefore, suggest that introducing this assay to replace currently available "antibody only" detection kits should be done with caution, unless it is based on cost implications. Further, this assay cannot be used to replace Nucleic Acid based Techniques (NAT) or core antigen-only-based assays in routine blood transfusion. Finally, Monolisa ${ }^{\circledR} \mathrm{HCV} A g-A b$ ULTRA assay cannot be used alone for $\mathrm{HCV}$ diagnosis in immunocompromised patients.

\section{ACKNOWLEDGEMENT}

We acknowledge the Catholic Academic Exchange Service (KAAD) in Bonn, Germany, for supporting this work.

\section{REFERENCES}

1. Lauer GM, Walker BD. Hepatitis C virus infection. The New England journal of medicine. 2001; 345 (1):41-52.

2. Aceijas C, Rhodes T. Global estimates of prevalence of $\mathrm{HCV}$ infection among injecting drug users. The International journal on drug policy. 2007; 18(5):352-8.

3. Mathei C, Robaeys G, van Damme P, Buntinx F, Verrando R. Prevalence of hepatitis $\mathrm{C}$ in drug users in Flanders: determinants and geographic differences. Epidemiology and infection. 2005; 133(1):127-36
4. Taziki O, Espahbodi F. Prevalence of hepatitis C virus infection in hemodialysis patients. Saudi journal of kidney diseases and transplantation. 2008; 19(3):475-8.

5. Almroth G, Ekermo B, Mansson AS, Svensson $\mathrm{G}$, Widell A. Detection and prevention of hepatitis $\mathrm{C}$ in dialysis patients and renal transplant recipients. A long-term follow up (1989-January 1997). Journal of internal medicine. 2002; 251(2):119-28.

6. Yang CS, Chang HH, Chou CC, Peng SJ. Isolation effectively prevents the transmission of hepatitis $\mathrm{C}$ virus in the hemodialysis unit. Journal of the Formosan Medical Association. 2003; 102(2):79-85.

7. Silva LK, Silva MB, Rodart IF, Lopes GB, Costa FQ, Melo ME, et al. Prevalence of hepatitis $\mathrm{C}$ virus (HCV) infection and $\mathrm{HCV}$ genotypes of hemodialysis patients in Salvador, Northeastern Brazil. Brazilian journal of medical and biological research. 2006; 39(5):595-602.

8. Goldberg D, McIntyre PG, Smith R, Appleyard K, Dunlop J, Taylor A, et al. Hepatitis C virus among high and low risk pregnant women in Dundee: unlinked anonymous testing. BJOG: an international journal of obstetrics and gynaecology. 2001; 108(4):365-70.

9. Vandelli C, Renzo F, Romano L, Tisminetzky S, De Palma M, Stroffolini T, et al. Lack of evidence of sexual transmission of hepatitis $\mathrm{C}$ among monogamous couples: results of a 10year prospective follow-up study. The American journal of gastroenterology. 2004; 99(5):855-9.

10. Magder LS, Fix AD, Mikhail NN, Mohamed MK, Abdel-Hamid M, Abdel-Aziz F, et al. Estimation of the risk of transmission of hepatitis $\mathrm{C}$ between spouses in Egypt based on seroprevalence data. International journal of epidemiology. 2005; 34(1):160-5.

11. Thomas DL, Leoutsakas D, Zabransky T, Kumar MS. Hepatitis $\mathrm{C}$ in HIV-infected individuals: cure and control, right now. Journal of the International AIDS Society. 2011; 14:22.

12. Mboto CI, Fielder M, Davies-Russell A, Jewell AP. Prevalence of HIV-1, HIV-2, hepatitis C and co-infection in The Gambia. West African journal of medicine. 2009; 28(1):16-9.

13. Onakewhor JU, Okonofua FE. The prevalence of dual human immunodeficiency virus/hepatitis $\mathrm{C}$ virus (HIV/HCV) infection in asymptomatic pregnant women in Benin City, Nigeria. African journal of reproductive health. 2009; 13(2):97108. 
14. Amin J, Kaye M, Skidmore S, Pillay D, Cooper DA, Dore GJ. HIV and hepatitis C coinfection within the CAESAR study. HIV medicine. 2004; 5(3):174-9.

15. Walusansa V, Kagimu M. Screening for hepatitis C among HIV positive patients at Mulago hospital in Uganda. African health sciences. 2009; 9(3):143-6.

16. Muriuki BM, Gicheru MM, Wachira D, Nyamache AK, Khamadi SA. Prevalence of hepatitis $\mathrm{B}$ and $\mathrm{C}$ viral co-infections among HIV-1 infected individuals in Nairobi, Kenya. BMC research notes. 2013; 6:363.

17. McDonald GB, Hinds MS, Fisher LD, Schoch HG, Wolford JL, Banaji $M$, et al. Venoocclusive disease of the liver and multiorgan failure after bone marrow transplantation: a cohort study of 355 patients. Annals of internal medicine. 1993 15; 118(4):255-67.

18. Sebagh M, Debette M, Samuel D, Emile JF, Falissard B, Cailliez V, et al. "Silent" presentation of veno-occlusive disease after liver transplantation as part of the process of cellular rejection with endothelial predilection. Hepatology. 1999; 30(5):1144-50.

19. Kumar S, DeLeve LD, Kamath PS, Tefferi A. Hepatic veno-occlusive disease (sinusoidal obstruction syndrome) after hematopoietic stem cell transplantation. Mayo Clinic proceedings Mayo Clinic. 2003; 78(5):589-98.

20. El-Sayed MH, El-Haddad A, Fahmy OA, Salama, II, Mahmoud HK. Liver disease is a major cause of mortality following allogeneic bone-marrow transplantation. European journal of gastroenterology \& hepatology. 2004; 16(12):1347-54.

21. Lee SH, Yoo KH, Sung KW, Koo HH, Kwon YJ, Kwon MM, et al. Hepatic veno-occlusive disease in children after hematopoietic stem cell transplantation: incidence, risk factors, and outcome. Bone marrow transplantation. 2010; 45(8):1287-93.

22. Mukherjee S, Mahmoudi TM, Mukherjee U. Liver transplant for viral hepatitis and fulminant hepatic failure. Minerva gastroenterologica $e$ dietologica. 2009; 55(1):83-100.

23. Krajden M, Shivji R, Gunadasa K, Mak A, McNabb G, Friesenhahn M, et al. Evaluation of the core antigen assay as a second-line supplemental test for diagnosis of active hepatitis C virus infection. Journal of clinical microbiology. 2004; 42(9):4054-9.
24. Fabrizi F, Lunghi G, Aucella F, Mangano S, Barbisoni F, Bisegna S, et al. Novel assay using total hepatitis $\mathrm{C}$ virus (HCV) core antigen quantification for diagnosis of HCV infection in dialysis patients. Journal of clinical microbiology. 2005; 43(1):414-20.

25. Tuke PW, Grant PR, Waite J, Kitchen AD, Eglin RP, Tedder RS. Hepatitis C virus window-phase infections: closing the window on hepatitis $\mathrm{C}$ virus. Transfusion. 2008; 48(4):594-600.

26. Welte K, Keever CA, Levick J, Bonilla MA, Merluzzi VJ, Mertelsmann R, et al. Interleukin-2 production and response to interleukin- 2 by peripheral blood mononuclear cells from patients after bone marrow transplantation: II. Patients receiving soybean lectin-separated and T cell-depleted bone marrow. Blood. 1987; 70(5):1595-603.

27. Soiffer RJ, Bosserman L, Murray C, Cochran K, Daley J, Ritz J. Reconstitution of T-cell function after CD6-depleted allogeneic bone marrow transplantation. Blood. 1990; 75(10):2076-84.

28. Keever CA, Small TN, Flomenberg N, Heller G, Pekle K, Black P, et al. Immune reconstitution following bone marrow transplantation: comparison of recipients of T-cell depleted marrow with recipients of conventional marrow grafts. Blood. 1989; 73(5):1340-50.

29. Ault KA, Antin JH, Ginsburg D, Orkin SH, Rappeport JM, Keohan ML, et al. Phenotype of recovering lymphoid cell populations after marrow transplantation. The Journal of experimental medicine. 1985; 161(6):1483-502.

30. Parreira A, Smith J, Hows JM, Smithers SA, Apperley J, Rombos Y, et al. Immunological reconstitution after bone marrow transplant with Campath-1 treated bone marrow. Clinical and experimental immunology. 1987; 67(1):142-50.

31. Roux E, Helg C, Dumont-Girard F, Chapuis B, Jeannet M, Roosnek E. Analysis of T-cell repopulation after allogeneic bone marrow transplantation: significant differences between recipients of T-cell depleted and unmanipulated grafts. Blood. 1996; 87(9):3984-92.

32. Roux E, Dumont-Girard F, Starobinski M, Siegrist CA, Helg C, Chapuis B, et al. Recovery of immune reactivity after T-cell-depleted bone marrow transplantation depends on thymic activity. Blood. 2000; 96(6):2299-303.

33. Wu CJ, Chillemi A, Alyea EP, Orsini E, Neuberg D, Soiffer RJ, et al. Reconstitution of $\mathrm{T}$-cell receptor repertoire diversity following $\mathrm{T}$ cell depleted allogeneic bone marrow 
transplantation is related to hematopoietic chimerism. Blood. 2000; 95(1):352-9.

34. Sy T, Jamal MM. Epidemiology of hepatitis C virus $(\mathrm{HCV})$ infection. International journal of medical sciences. 2006; 3(2):41-6.

35. Ly TD, Laperche S, Brennan C, Vallari A, Ebel A, Hunt J, et al. Evaluation of the sensitivity and specificity of six HIV combined p24 antigen and antibody assays. Journal of virological methods. 2004; 122(2):185-94.

36. Guidelines for laboratory testing and result reporting of antibody to hepatitis $\mathrm{C}$ virus. Centers for Disease Control and Prevention. Morbidity and Mortality Weekly Report. 2003 http://www.ncbi.nlm.nih.gov/pubmed/12585742

37. Schnuriger A, Dominguez S, Valantin MA, Tubiana R, Duvivier C, Ghosn J, et al. Early detection of hepatitis $C$ virus infection by use of a new combined antigen-antibody detection assay: potential use for high-risk individuals. Journal of clinical microbiology. 2006; 44(4):1561-3.

38. Schuttler CG, Thomas C, Discher T, Friese G, Lohmeyer J, Schuster R, et al. Variable ratio of hepatitis $\mathrm{C}$ virus RNA to viral core antigen in patient sera. Journal of clinical microbiology. 2004; 42(5):1977-81.

39. 39. Bouvier-Alias $M$, Patel $K$, Dahari $H$, Beaucourt S, Larderie P, Blatt L, et al. Clinical utility of total $\mathrm{HCV}$ core antigen quantification: a new indirect marker of $\mathrm{HCV}$ replication. Hepatology. 2002; 36(1):211-8.

40. Maillard P, Krawczynski K, Nitkiewicz J, Bronnert C, Sidorkiewicz M, Gounon P, et al. Nonenveloped nucleocapsids of hepatitis $\mathrm{C}$ virus in the serum of infected patients. Journal of virology. 2001; 75(17):8240-50.

41. Ansaldi F, Bruzzone B, Testino G, Bassetti M, Gasparini R, Crovari P, et al. Combination hepatitis $\mathrm{C}$ virus antigen and antibody immunoassay as a new tool for early diagnosis of infection. Journal of viral hepatitis. 2006; 13(1):5-10.

42. Nubling CM, Unger G, Chudy M, Raia S, Lower J. Sensitivity of $\mathrm{HCV}$ core antigen and $\mathrm{HCV}$ RNA detection in the early infection phase. Transfusion. 2002; 42(8):1037-45.
43. Rosenberg NE, Kamanga G, Phiri S, Nsona D, Pettifor A, Rutstein SE, et al. Detection of acute HIV infection: a field evaluation of the determine(R) HIV-1/2 Ag/Ab combo test. The Journal of infectious diseases. 2012; 205(4):528-34.

44. Dean L, Perry K, Nichol ST. Evaluation of MONOLISA HCV Ag-Ab ULTRA. Health Promotion Agency-Microbial Diagnostics Assessment Service, Evaluations and Standards Laboratory Report PER 06001. 2006. http://www.hpa.org.uk/webc/hpawebfile/hpaweb _c/1317133424701

45. Courouce AM, Le Marrec N, Bouchardeau F, Razer A, Maniez M, Laperche S, et al. Efficacy of $\mathrm{HCV}$ core antigen detection during the preseroconversion period. Transfusion. 2000; 40(10):1198-202.

46. Muerhoff AS, Jiang L, Shah DO, Gutierrez RA, Patel J, Garolis C, et al. Detection of HCV core antigen in human serum and plasma with an automated chemiluminescent immunoassay. Transfusion. 2002; 42(3):349-56.

47. Shah DO, Chang CD, Jiang LX, Cheng KY, Muerhoff AS, Gutierrez RA, et al. Combination HCV core antigen and antibody assay on a fully automated chemiluminescence analyzer. Transfusion. 2003; 43(8):1067-74.

48. Laperche S, Elghouzzi MH, Morel P, AssoBonnet M, Le Marrec N, Girault A, et al. Is an assay for simultaneous detection of hepatitis $\mathrm{C}$ virus core antigen and antibody a valuable alternative to nucleic acid testing? Transfusion. 2005; 45(12):1965-72.

49. Leary TP, Gutierrez RA, Muerhoff AS, Birkenmeyer LG, Desai SM, Dawson GJ. A chemiluminescent, magnetic particle-based immunoassay for the detection of hepatitis $\mathrm{C}$ virus core antigen in human serum or plasma. Journal of medical virology. 2006; 78(11):143640.

50. Laperche S, Le Marrec N, Girault A, Bouchardeau F, Servant-Delmas A, ManiezMontreuil M, et al. Simultaneous detection of hepatitis $\mathrm{C}$ virus (HCV) core antigen and anti$\mathrm{HCV}$ antibodies improves the early detection of HCV infection. Journal of clinical microbiology. 2005; 43(8):3877-83. 